

\title{
A Three-level Analysis of Turkey's Crisis with the U.S.-led Order
}

\author{
ALi BALCI*
}

ABSTRACT Starting in 2013, Turkish-American relations have been undergoing one of the deepest and most alarming crises since the 1940s. Ankara, a NATO member and U.S. ally for more than six decades, not only defies U.S. interests in the Middle East, as in the cases of Iran and Syria, it also works with Russia on many strategic issues, such as buying high-tech weapons, building a nuclear power plant, and negotiating the Syrian crisis. In order to explain why Turkey, as a subordinate actor in the U.S.-led order, pursues policies that are incongruent with U.S. interests, this paper employs a hierarchy approach in order to identify when and why subordinate states challenge the lead state and its rules and dictates.

* Sakarya University, Middle East Institute, Turkey tarting in 2013, Turkey experienced its deepest and most alarming crisis with the U.S.-led order, leading The New York Times' editorial board to issue an open warning: "Turkey has prospered as a NATO member. That means it is likely to be the big loser if it forsakes the West for, say, closer ties with Russia." In June 2018, 44 members of the House of Representatives warned U.S. Secretary of Defense James Mattis in a letter saying that Turkey, "in addition to its threats against the United States, ... has made a common practice of aggressively targeting U.S. allies, while aiding and abetting our adversaries." ${ }^{3}$ Although many pundits and policymakers embraced Turkey's shift of axis as an explanation for the recent crisis, ${ }^{4}$ the prophetic, exit-oriented debate that surrounds this explanation is misleading for three simple reasons. First, history proves that such debates have poor predictability power. For example, Turkey's crisis with the U.S. in the 1970s triggered a similar debate, ${ }^{5}$ but Turkey remained within the U.S.-led order. Second, the exit-oriented debate overshadows Turkey's search for greater autonomy within the U.S.-led order. Finally, such a conceptualization of Turkey's crisis with the U.S. is value-laden, simply because it constructs Turkey as inferior against the superior West. ${ }^{6}$ 


\section{Given the fact that the YPG}

is the Syrian branch of the

PKK, a terrorist organization

targeting Turkey's unity,

Ankara perceived the U.S.-YPG

collaboration as an existential

threat to its own security would have given the U.S. the right to use Turkish territories for the invasion of Iraq. ${ }^{7}$ Both Turkey and the U.S. took some appeasing steps after these crises in order to save the initial contract, mostly because both sides continued to gain from the hierarchical relation. While the U.S.-led order provided numerous benefits to Turkey, such as cheaper security, continuing economic/military aid, the delivery of bail-outs in harsh economic conditions, a respected status in the West, and political advantages in its relations with the neighboring countries, the U.S. in return gained a great deal from Turkey, anchoring the U.S.-led order's eastern flank and hosting military airbases central to U.S. interests in the Middle East.

The sustainability of the hierarchical relation between the U.S. and Turkey, however, has faced grave and mounting challenges since the early 2010 s. Although Ankara disrupted the U.S. sanctions over Iran by being the major buyer of Iranian oil and gas, and paying for these purchases through the export of gold to Iran, Turkey continued to be a strategic ally of the U.S. in the Syrian crisis until late 2013. However, the rise of the Islamic State of Iraq and Syria (ISIS) was a turning point. On the one hand, the Western media and American policymakers implicitly accused the Turkish government of supporting radical groups in Syria, including ISIS. On the other, the U.S. declared the YPG (the People's Protection Units) as its tactical ally in the war against ISIS and started to generously arm the group with high-tech weapons. ${ }^{8}$ 


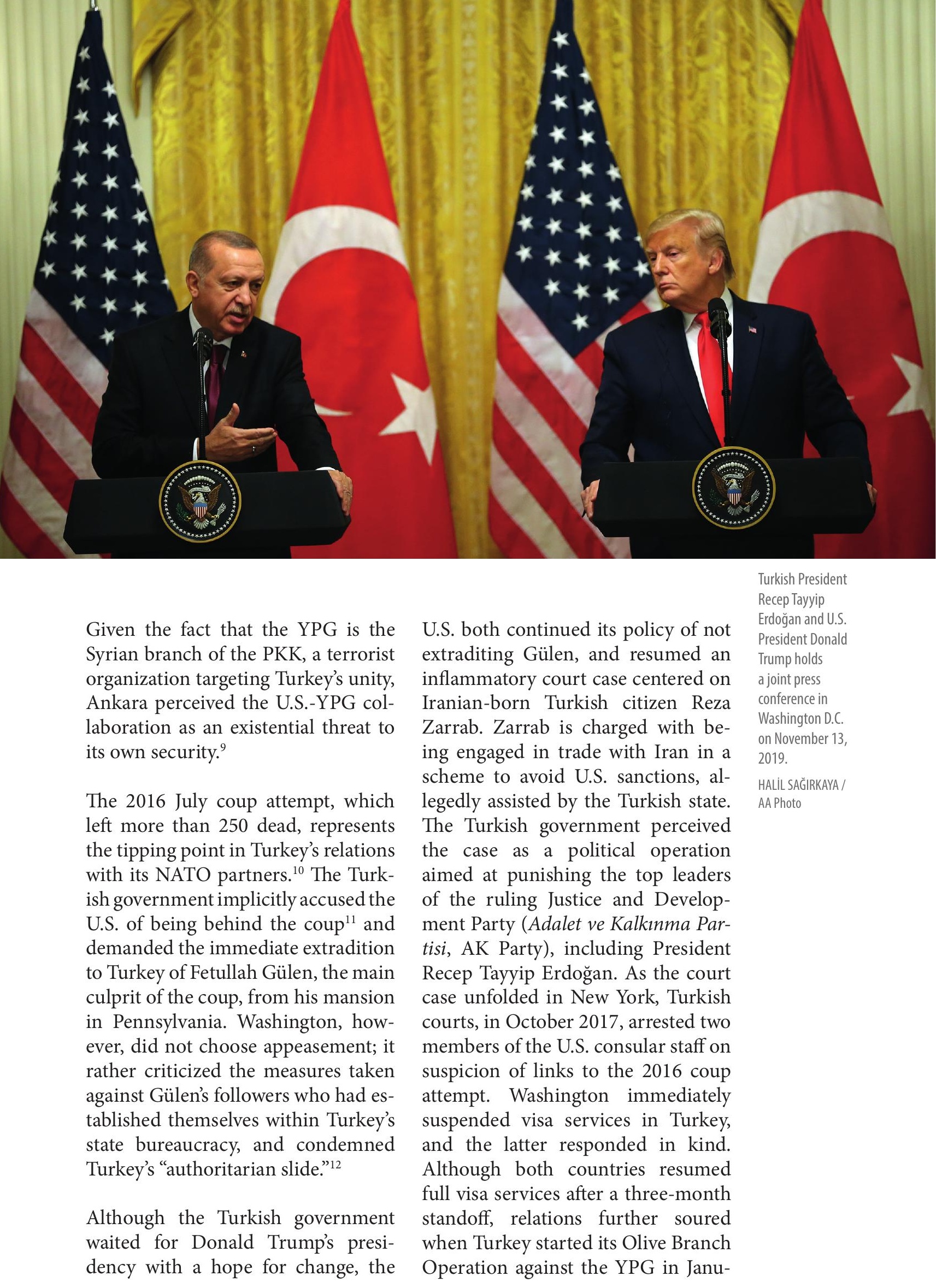


ary 2018. Given the U.S.' tactical alliance with the YPG, the Olive Branch Operation in Afrin, Syria, turned into a sort of proxy war between Turkey and the U.S.

While the crisis between Turkey and the U.S. has grown deeper, Ankara's relations with Russia have dramatically improved, despite a one-year break after the downing of a Russian jet by a Turkish warplane on November 24, 2015 in the Syrian war theater. Growing economic relations between Ankara and Moscow had already risen to the level of 'strategic partnership' in 2010 with the signing of a pact to build Turkey's first nuclear power plant. ${ }^{13}$ However, this partnership was overshadowed by diverging policies in the Syrian crisis for a long time. After the 2016 July bloody coup attempt, Turkey not only started to work together with Russia in the Syrian crisis, it also signed an accord for Moscow to supply Ankara with S-400 surfaceto-air missile batteries. The last step alarmed Turkey's NATO partners, hitting the headline in the West as "the clearest sign of Turkey's pivot toward Russia and away from NATO and the West." ${ }^{14}$ In short, Turkey is challenging the U.S. position in many areas: in its prominent role in the resolution of the Syrian crisis, its purchase of high-technology weapons from a rival hierarchy, its relations with Iran, its recognition of the YPG as a terrorist movement, its contestation of the future of Fetullah Gülen, and so forth. Despite these myriad disagreements, Ankara has never questioned the value of the NATO Alliance, nor declared an intention to shift to rival hierarchical orders.

\section{Understanding the Crisis}

The following section explores why the Turkish state is challenging its great power patron, the U.S., in the international system. Accordingly, it sorts out three main clusters of expla-

Figure 1: Hypotheses about Challenging Behaviors of Subordinates ${ }^{15}$

\begin{tabular}{|c|c|c|}
\hline Levels & No & Explanations \\
\hline \multirow{3}{*}{ 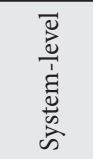 } & H1a & In a unipolar system, challenge is less likely \\
\hline & $\mathrm{H} 1 \mathrm{~b}$ & In a multi- or bipolar system, challenge is more likely \\
\hline & $\mathrm{H} 1 \mathrm{c}$ & Challenge of subordinates close to a rival great power is less likely \\
\hline \multirow{3}{*}{ 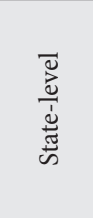 } & $\mathrm{H} 2 \mathrm{a}$ & $\begin{array}{l}\text { The greater the improvement in material capacities, the greater the likelihood } \\
\text { that subordinates will challenge }\end{array}$ \\
\hline & $\mathrm{H} 2 \mathrm{~b}$ & $\begin{array}{l}\text { If the importance of hierarchy decreases for domestic politics, challenge is more } \\
\text { likely }\end{array}$ \\
\hline & $\mathrm{H} 2 \mathrm{c}$ & Democratic countries are less prone to posing risky challenges to the lead state \\
\hline \multirow{3}{*}{ 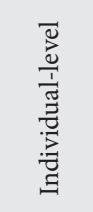 } & $\mathrm{H} 3 \mathrm{a}$ & Leaders with a grandiose vision are more likely to challenge \\
\hline & $\mathrm{H} 3 \mathrm{~b}$ & $\begin{array}{l}\text { Freedom from domestic constraints increases the likelihood of a grandiose } \\
\text { leaders' challenge }\end{array}$ \\
\hline & $\mathrm{H} 3 \mathrm{c}$ & $\begin{array}{l}\text { Grandiose leaders surrounded by like-minded advisors are more likely to } \\
\text { challenge }\end{array}$ \\
\hline
\end{tabular}


nations by focusing on three different levels of analysis: system ( $\mathrm{H} 1)$, state $(\mathrm{H} 2)$, and individual $(\mathrm{H} 3)$ respectively. Each cluster includes three potential causes.

For almost two decades after the Cold War, the U.S. maintained a near monopoly on the use of force in regions around Turkey, the Middle East, and Eastern Europe. ${ }^{16}$ This U.S.-led order continuously expanded against Russian interests until the closing years of the first decade of the 2000s. Russia countered the U.S. influence first in Georgia by using military power against pro-Western political actors there in 2008. Russia's military intervention into Georgia encapsulated its desire to proclaim its comeback on the world stage as a competitor against U.S. primacy. ${ }^{17}$ Moscow continued to follow an "assertive" and "competitive" strategy both in Ukraine and in Syria to prevent further damage to Russia's "regional leadership." 18 Thanks to the U.S. retrenchment, and the weakening of U.S. credibility after President Barack Obama's "failure to reinforce America's 'red line' in Syria," Russia gained a more assertive footprint in the Middle East. ${ }^{19}$ Another sign of Russia's return as a great power balancer (alternative hierarchical center) is the recent expansion of Moscow-led economic organizations. By using its asymmetrical power capabilities, Russia put pressure over many neighboring countries to join such organizations as the Collective Security Treaty Organization and the Eurasian Economic Union. ${ }^{20}$ In addition to its military and economic influence, Moscow promoted "counter-norms"

\section{For almost two decades after the Cold War, the U.S. maintained a near monopoly on the use of force in regions around Turkey, the Middle East, and Eastern Europe}

against U.S.-promoted norms such as democracy and human rights. ${ }^{21}$ Those counter-norms not only consolidate a Russia-led 'counter order', they also attract potential subordinates.

The military engagements and increasing influence of Russia in the region around Turkey affected Ankara's strategic choices in three dramatic ways. First, unlike the unipolar system of the 1990s and the following decade (H1a), Turkey now has a potential great power balancer while the U.S. thus demands more certainty about and control over Turkey's behavior (H1b). This situation makes Ankara more opportunistic and therefore defiant toward the wishes of the U.S., particularly regarding the future of Syria. Second, the theoretical premise holds that the rise of a potential competitor will likely lead to a more favorable bargain for subordinates if they have no substitute in their region for the interests of the lead state. ${ }^{22}$ Therefore, NATO allies, "alarmed at a resurgent Russia," to use the words of former U.S. Secretary of State Rex Tillerson, ${ }^{23}$ will likely give way to compromises, leading to the rise of Ankara's autonomy, in order to keep Turkey 


\section{Although today's Russia does}

not pose any direct threat to

Turkey, its assertive record in

Georgia, Ukraine, and Syria

has already fomented fear of

uncertainties, making Ankara

very cautious about a possible

slide to the Russia-led order in the continued hierarchy (H1b). Third, Russia is the giant neighbor of Turkey through the Black Sea (H1c). Countries that are more threatened by a contiguous great power are more likely to subordinate themselves to an out-of-area great power. ${ }^{24}$ This was the case for Turkey after the Second World War. Although today's Russia does not pose any direct threat to Turkey, its assertive record in Georgia, Ukraine, and Syria has already fomented fear of uncertainties, making Ankara very cautious about a possible slide to the Russia-led order.

But what differentiates Ankara from other similarly situated countries such as Greece in utilizing the rise of a potential balancer for a better deal with the U.S.-led order? At the state level, Turkey has experienced two essential changes since the early 2000 s. First, the material capacities of Turkey improved dramatically, making Ankara more independent from the U.S.-led order (H2a). If secondary states trade their sovereignty for security, improvements in their material capacity will change the conditions under which the initial bargaining took place. Consequently, the secondary state with a better self-help capacity will either attempt to increase its autonomy within the existing hierarchical order or choose to behave free from the rules of that order. If the improvement of material capacity makes the subordinate a new great power, it will demand more autonomy without the need for a balancer. ${ }^{25}$ However, if there is improvement but not enough to become a great power, the subordinate will likely challenge the hegemon only when a great power balancer is around (H1b). The latter has been the case for post-2013 Turkey, simply because dramatic increases in its material capacities resulted in 'status inconsistency', that is, a difference between the status that is attributed by the U.S. and the status that is actually deserved. ${ }^{26}$

In parallel with the rise of Russian engagement, improvement in Turkey's material capacity throughout the first decade of the 2000s clearly resulted in dissatisfaction in Ankara over its ascribed status, and laid the foundations for a more assertive foreign policy. ${ }^{27}$ In the aftermath of the 2001 crisis, the Turkish economy performed well in comparison to its own historical standards, its success epitomized in the increase of GDP from $\$ 200$ billion in 2001 to $\$ 950$ billion in 2013, according to World Bank data. Although Turkey's military expenditure increased from \$7 billion in 2001 to $\$ 19$ billion in 2013, the real game changer was the rise in Turkey's investment in its indigenous 
defense industry. ${ }^{28}$ The U.S. arms embargo on Turkey in 1974 was a turning point. The U.S. was supplying “over 90 percent of Turkey's military equipment" at the time, ${ }^{29}$ and therefore Ankara decided to invest in an indigenous defense industry in order to act independently in protecting its interests in Cyprus, and to decrease its susceptibility to arms embargoes. Although Turkey had established the foundation of its future indigenous defense industry during the 1980s, the AK Party rule witnessed a dramatic improvement in it. The rate at which Turkey's defense industry met Ankara's procurement requirements rose from 24 percent in 2012 to 64 percent in $2016 .{ }^{30}$ Consequently, improvements in Turkey's military capacity made two military operations in Syria more efficacious, the first against ISIS in 2016-2017, and the second against the YPG in early 2018.

Since the late Ottoman period, the Turkish people had internalized a perception that their country is 'behind' the West, and that it is inevitable to embrace Western judgment. ${ }^{31}$ In other words, an active residue or sediment of Turkey's centuries-long experience with the West not only functions within its present, it also continues to shape the perception of the ruling elite and ordinary people (H2b). However, the credibility of the U.S.-led hierarchy in Turkey is currently being challenged by its changing function in its domestic power setting. This is the second essential change at the state level. Until the AK Party's coming to power in 2002, Turkey's cordial relation with the West was more than a simple security pact; it was rather an integral part of domestic legitimacy politics. Here Turkey's Westernization policy, as a "strategic resource" that actors could mobilize in pursuit of diverse goals, ${ }^{32}$ played a key role in rendering the founding ideology of the state, Kemalism, to be preferred and privileged. After being crushed in 1997 by the Turkish Armed Forces, the self-appointed guardian of the state ideology, Turkey's political Islamists transformed their anti-Western language and came to power again in 2002. In its first years in power, the AK Party rendered Turkey's EU accession process an instrumental tool in delegitimizing the tutelage power of the state bureaucracy over elected politicians. After the AK Party knocked down the guardians of the old regime, including the Turkish Armed Forces in the early 2010s, the necessity of close relations with the West diminished, lost its appeal and function for power holders in Turkey. Not surprisingly, when U.S. officials increasingly criticized Turkey's cooperation with non-Western powers such as Russia and pressured to demonstrate its commitment to Western partnership and prove its role as a reliable ally throughout the 2010s, the AK Party government used this criticism as an opportunity to consolidate its own power and marginalize its political rivals and the dissident social classes. ${ }^{33}$

Although "populist majoritarianism" has increasingly dominated daily politics, Turkey still maintains the formal institutions of a procedural democracy, such as free elections, and political parties. ${ }^{34}$ Although the 


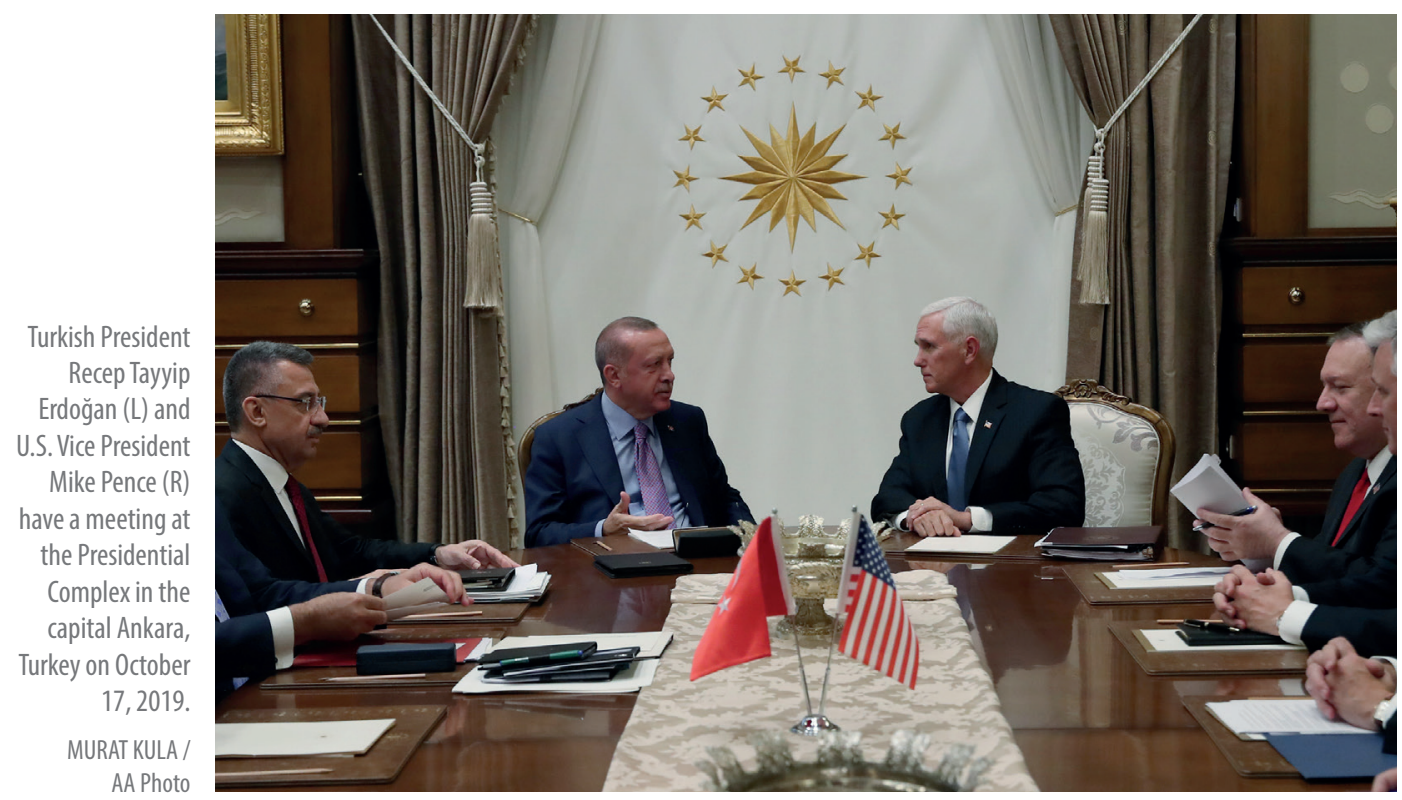

AK Party capitalizes on anti-U.S. sentiments and searches for soulmates in emerging non-Western orders, ${ }^{35}$ oppositional parties exist, and the Kemalist secular ideology is still a broad-based opposition movement in Turkey. It is necessary, therefore, to underline that any serious challenge to the U.S.-led order, coupled with economic and political crises, is likely to increase the audience cost for the AK Party in the upcoming elections (H2c). For example, foreign policy troubles and a stalling economy played an important role in the 2019 municipality elections, wherein the AK Party lost two of Turkey's biggest cities, İstanbul and Ankara. Furthermore, because grand strategic choices are risky and costly, the AK Party is unlikely to relinquish the benefits of the U.S.-led system and renounce the U.S.-led hierarchical order. Although ideological divergence between the
U.S.-led order and the new rulers of Turkey increases the likelihood of challenge (H2b), Turkey's overall democratic system makes the AK Party extremely cautious about putting its benefits from the U.S.-led order at risk (H2c). Turkey's economic integration with the West has generated an indispensable wealth.

For decades, two important dynamics have shaped Turkish politics. First, the Turkish Armed Forces exercised a tutelary power over elected politicians. Second, most of the governments were coalitions and short-lived, increasing advisors' influence over political leaders. Erdoğan, an exceptionally charismatic leader, not only rendered the hitherto impregnable institutions of the Kemalist regime submissive (H3b), he also built a 15-year political experience, making all of the potential advisors unfledged in state 
affairs (H3c). In addition, two critical developments have made Erdoğan stand outside his own party and overcome "strong institutions" such as the parliament and the cabinet. While the domestic political turmoil after 2013 eliminated Erdoğan's potential balancers within the party, including the former President Abdullah Gül, and former Foreign Minister and Prime Minister Ahmet Davutoğlu, the 2017 constitutional reform enlarged the power of the presidency against other elected state institutions (H3b). Given the fact that the role of leaders is "most visible when international hierarchies are first emerging or when actors are transitioning from one hierarchy to another," ${ }^{36}$ Erdoğan's image has played a significant role in Turkey's mounting crisis with the U.S. and will likely matter a great deal in Turkey's future within the U.S.-led order (H3a).

Barış Kesgin, in his data-driven studies analyzing Erdoğan's interviews and press conference responses, finds that Erdoğan has a personality that focuses "on taking advantage of opportunities," 37 and that he "respects constraints." 38 Another recent operational-code-based study of Erdoğan's personality also finds that he "pursues shared interests by following flexible strategies and shuns brinkmanship as much as possible." ${ }^{39}$ Throughout the post-2013 crisis with the U.S.-led order, Erdoğan has used opportunities to advance Turkey's autonomy within the U.S.-led hierarchical order, but has never given the final verdict, i.e. he has never initiated an exit from it. In other words, Erdoğan has followed a strategy of 'two steps forward one

\section{Throughout the post-2013} crisis with the U.S.-led order, Erdoğan has used opportunities to advance Turkey's autonomy within the U.S.-led hierarchical order

step back' through which he has been able to increase Turkey's autonomy without risking its secure position in world politics. For example, in September 2013, Turkey made a tentative agreement to purchase a $\$ 3.4$ billion long-range missile defense system from a Chinese company and cancelled this agreement in November 2015 after harsh reactions from its NATO allies. During the S-400 crisis, Erdoğan also pushed the limits of Turkey's NATO allies, but never questioned Turkey's place in NATO.

\section{Conclusion}

To evaluate the above arguments, we have a mixed inference about the causes of Turkey's crisis with the U.S.-led order. While H1b, H2a (partly), H2b, H3a (partly), H3b and $\mathrm{H} 3 \mathrm{c}$ are causal dynamics behind Ankara's challenging behaviors against the U.S., H1c, H2a (partly), H2c, and $\mathrm{H} 3 \mathrm{a}$ (partly) mitigate the magnitude of those behaviors. Therefore, we are currently witnessing significant challenges by Turkey against U.S. interests together with many compromising steps. Throughout the crisis, Turkey's 
ruling leaders, for example, never questioned Turkey's place in NATO, the main military alliance of the U.S.-led order. In May 2019, Erdoğan overtly stated that Turkey's purchase of the S-400 missile defense systems does not mean that Ankara is seeking "alternatives" in its relations with the West. ${ }^{40}$ Turkey also compromised about Andrew Brunson, an American clergyman who had been in Turkish custody for two years, when the crisis in relations peaked after the Trump administration's economic sanctions against Turkey in 2018.

What can we say about the popular question: will Turkey exit from the U.S.-led order? To start with, it should be noted that while systemic variables make Turkey more opportunistic and demanding within the U.S.-led order, they also keep Turkey within this order. If Washington offers a better deal, making Turkey, say, more autonomous in dealing with the PKK and its branches in the Middle East, and solving Turkey's recognition problem, ${ }^{41}$ an out-of-area patron (the U.S.) would be preferable to a contiguous one (Russia). ${ }^{42}$ Although recent improvements in Turkey's material capacity motivate Ankara to behave more opportunistically, these improvements have not made Turkey powerful enough to exit from the U.S.-led order without being a subordinate in a different hierarchical order. This leaves Ankara with a tough question, namely whether Russia's engagement in the region has a future. While Russia is strong enough in military power, its economy will likely fall short in financing its asser- tive ambitions. ${ }^{43}$ Domestic variables also support the 'no future shift' argument for Turkey. In a democratic country where the opposition is on the alert, the ruling party will likely avoid taking risky and costly steps, and opt to continue to exploit opportunities without making any grand strategic choice. Moreover, the image of Erdoğan supports such an inference.

\section{Endnotes}

1. This research was made possible by a grant (118K413), from the Scientific and Technological Research Council of Turkey, (TÜBITAK).

2. The Editorial Board, "Some Urgent Questions About Turkey," The New York Times, (October 13, 2017), retreived February 10, 2018, from https:// www.nytimes.com/2017/10/13/opinion/turkeyerdogan-nuclear-weapons.html.

3. "Letter to the Honorable James N. Mattis, Secretary of Defense-Prevent Turkey from Acquiring F-35 Fighter Jet," United States House of Representatives, (June 15, 2018), retrieved July 20, 2018, from https://sarbanes.house.gov/sites/ sarbanes.house.gov/files/Turkey_F35_Letter_FINAL_SIGNED.pdf.

4. Ali Balcı, Filiz Cicioğlu, and Dilek Küçükboz, "Türkiye'nin Ekseni Kayıyor mu? Bir Literatür Değerlendirmesi [ls There a Shift in Turkey's Axis? A Literature Review]," Akademik Araştırmalar ve Çalışmalar Dergisi, Vol. 11, No. 20 (2019), pp. 66-81.

5. "Verlassen die Türken die Nato? [Turks Leaving NATO?]" Spiegel Online, No. 13 (March 21, 1977), pp. 136-137, 140, retrieved from https://magazin. spiegel.de/EpubDelivery/spiegel/pdf/40941772; Nicholas Gage, "'Turks' Eastern Ties Worrying the West," The New York Times, (April 28, 1978), retrieved from https://www.nytimes.com/1978/04/ 28/archives/turks-eastern-ties-worrying-thewest-nato-fears-us-arms-embargo-may.html.

6. Johanna Vuorelma, "The Ironic Western Self: Radical and Conservative Irony in the 'Losing Turkey' Narrative," Millennium, Vol. 47, No. 2 (2018), pp. 190-209.

7. Kemal Kirişçi, Turkey and the West: Fault Lines in a Troubled Alliance, (Washington D.C.: Brookings Institution Press, 2017); Ali Balcı, Türkiye Dış Politi- 
kası: Illkeler, Aktörler ve Uygulamalar [Turkey's Foreign Policy: Principles, Actors, Practices], (İstanbul: Alfa Yayınları, 2017).

8. Andrew Buncombe, "Donald Trump to Arm Syrian Kurds against ISIS Despite Turkish Opposition," Independent, (May 9, 2018), retrieved February 10, 2018, from http://www.independent.co.uk/ news/world/americas/trump-syria-kurds-armsisis-weapons-turkey-erdogan-anger-a7727031. html.

9. Ali Balcı, "Why Did Turkey Crash the 'Westernpromoted' Gains of PKK-led Kurds?" Political Reflection, April-May-June, No. 19 (2019), pp. 31-37.

10. Ali Balcı and Yıldırım Turan, "Eleştirinin Sefaleti: Batı'dan 15 Temmuz Darbe Girişimini Okumak [Poverty of Critique: Reading the July 15 Coup Attempt from the West]," Bilig, No. 83, (Spring 2017), pp. 53-77.

11. Victor Kotsev and John Dyer, "Turkey Blames U.S. for Coup Attempt," USA Today, (July 18, 2016), retrieved January 10, 2018, from https://www. usatoday.com/story/news/world/2016/07/18/ turkey-blames-us-coup-attempt/87260612/.

12. Justin Sink, "Crackdowns by Turkey's Erdogan Are 'Troubling,' Obama Says," Bloomberg, (April 02, 2016), retrieved February 10, 2018, from https:// www.bloomberg.com/news/articles/2016-04-01/ crackdowns-by-turkey-s-erdogan-are-troublingobama-says.

13. Emre Erşen, "Evaluating the Fighter Jet Crisis in Turkish-Russian Relations," Insight Turkey, Vol. 19, No. 4 (2017), pp. 85-103; Seçkin Köstem and Emre Erşen, Turkey's Pivot to Eurasia: Geopolitics and Foreign Policy in a Changing World Order, (London: Routledge, 2019).

14. Carlotta Gall and Andrew Higgins, "Turkey Signs Russian Missile Deal, Pivoting from NATO," The New York Times, (September 12, 2017), retrieved February 10, 2018, from https://www. nytimes.com/2017/09/12/world/europe/turkeyrussia-missile-deal.html.

15. The set of hypotheses given in the Figure are generated from hierarchy-based studies. See for this literature, Alexander Cooley, Logics of Hierarchy: The Organization of Empires, States, and Military Occupation, (Ithaca, NY: Cornell University Press, 2005); David A. Lake, Hierarchy in International Relations, (Ithaca, N. Y: Cornell University Press, 2009); David C. Kang, East Asia Before the West, (New York: Columbia University Press, 2010); Andrew Phillips, War, Religion and Empire: The Transformation of International Orders, (Cam- bridge: Cambridge University Press, 2011); Evelyn Goh, The Struggle for Order: Hegemony, Hierarchy and Transition in Post-Cold War East Asia, (Oxford: Oxford University Press, 2013); Alexander D. Barder, Empire Within: International Hierarchy and Its Imperial Laboratories of Governance, (London: Routledge, 2015); Vincent Pouliot, International Pecking Orders: Thee Politics and Practice of Multilateral Diplomacy, (Cambridge: Cambridge University Press, 2016); Seo-Hyun Park, Sovereignty and Status in East Asian International Relations, (Cambridge: Cambridge University Press, 2017); Ayşe Zarakol, (ed.), Hierarchies in World Politics, (Cambridge: Cambridge University Press, 2017); Michael Zürn, A Theory of Global Governance: Authority, Legitimacy, and Contestation (Oxford: Oxford University Press, 2018).

16. Central Asia was an exception. After the collapse of the Soviet Union, Russia pursued its hierarchy in its near abroad. For post-Soviet hierarchy, See, Alexander Cooley and Hendrik Spruyt, Contracting States: Sovereign Transfers in International Relations, (Princeton: Princeton University Press, 2009).

17. Deborah Welch Larson and Alexei Shevchenko, "Status Seekers: Chinese and Russian Responses to US Primacy," International Security, Vol. 34, No. 4 (2010), pp. 63-95, 91; Thomas Ambrosio, Challenging America's Global Preeminence: Russia's Quest for Multipolarity, (London: Ashgate, 2005).

18. Maria Raquel Freire and Regina Heller, "Russia's Power Politics in Ukraine and Syria: Status-seeking between Identity, Opportunity and Costs," Europe-Asia Studies, Vol. 70, No. 8 (2018), pp. 1185$1212,1187$.

19. Gareth Stansfield, Doug Stokes, and Saul Kelly, "UK Strategy in the Gulf and Middle East after American Retrenchment," Insight Turkey, Vol. 20, No. 4 (2018), pp. 231-247.

20. Elias Götz, "Putin, the State, and War: The Causes of Russia's Near Abroad Assertion Revisited," International Studies Review, Vol. 19, No. 2 (June 2017), p. 228.

21. Alexander Cooley, "Countering Democratic Norms," Journal of Democracy, Vol. 26, No. 3 (2015), pp. 49-63.

22. Lake, Hierarchy in International Relations, p. 88. G. John Ikenberry, Liberal Leviathan: The Origins, Crisis, and Transformation of the American World Order, (Oxford: Princeton University Press, 2011), pp. 98-99.

23. Joyce P. Kaufman, "The US Perspective on NATO under Trump: Lessons of the Past and Pros- 
pects for the Future," International Affairs, Vol. 93, No. 2 (2017), pp. 251-266, 252.

24. Lake, Hierarchy in International Relations, p. 142.

25. For example, secondary states with nuclear weapons will have little fear of aggression from the hegemonic state and thus will have little or no need to counterbalance against the paramount state. See, Daniel Deudney, "Hegemony, Nuclear Weapons, and Liberal Hegemony," in G. John Ikenberry (ed.), Power, Order and Change in World Politics, (Cambridge: Cambridge University Press, 2014), pp. 195-232, 215-216.

26. Şaban Kardaş, "Turkey: A Regional Power Facing a Changing International System," Turkish Studies, Vol. 14, No. 4 (2013).

27. Ziya Öniş and Mustafa Kutlay, "Rising Powers in a Changing Global Order: The Political Economy of Turkey in the Age of BRICs," Third World Quarterly, Vol. 34, No. 8 (2013), p. 1414; Emel Parlar Dal, Ali Murat Kurşun, and Hakan Mehmetcik, "Decoding Turkey's Institutional Accommodation in the Changing International Order: The UN and G20 Cases," International Politics, Vol. 56, No. 4 (2019), pp. 477-494; Furkan Halit Yolcu, "Ortadoğu Güvenlik Raporu: 2017 [Middle East Security Report 2017]," Ortadoğu Yıllığı 2017, Vol. 12, (Ankara, Kadim: 2018), pp. 493-513.

28. Ali Balcı and Cahit Çelik, "Turkey's Military Power in the 2000s: An Assessment for Measurement Methods," Turkish Policy Quarterly, Vol. 18, No. 2 (Summer 2019), pp. 101-111.

29. U.S. Department of State, Foreign Relations of the United States, 1969-1976, Greece; Cyprus; Turkey, 1973-1976, Vol. 30, (Washington, DC: Government Printing Office, 2007).

30. "Turkey Builds a Military-Industrial Complex to Match Its Ambitions," Stratfor, (May 26, 2017), retrieved February 10, 2018, from https://world view.stratfor.com/article/turkey-builds-militaryindustrial-complex-match-its-ambitions.

31. Ayşe Zarakol, After Defeat: How the East Learned to Live with the West, (Cambridge: Cambridge University Press, 2011), pp. 56, 39.

32. Christian Reus-Smit, "Cultural Diversity and International Order," International Organizations, Vol. 71, No. 4 (2017) pp. 851-885, 23.

33. Deepa Prakash and Aslı Ilgit, "More than a Feeling: Emotional Responses to International Criticism in Erdoğan's Turkey," Review of International Studies, Vol. 43, No. 1 (2017), pp. 130-151; Ali Balcı, Dış Politikada Hesaplaşmak: AK Parti Ordu ve Kemalizm [Confronting through Foreign Policy:
AK Party, Military and Kemalism], (İstanbul: Etkileşim Yayınları, 2015).

34. Ioannis N. Grigoriadis, Democratic Transition and the Rise of Populist Majoritarianism: Constitutional Reform in Greece and Turkey, (London: Palgrave Macmillan, 2017).

35. Shogo Suzuki, "'Delinquent Gangs' in International System Hierarchy," in Ayşe Zarakol (ed.), Hierarchies in World Politics, (Cambridge: Cambridge University Press, 2017), pp. 219-240, 231.

36. Daniel L. Byman and Kenneth M. Pollack, "Let Us Now Praise Great Men: Bringing the Statesman Back in," International Security, Vol. 25, No. 4 (2001), pp. 107-146, 142.

37. Barış Kesgin, "Leadership Traits of Turkey's Islamist and Secular Prime Ministers," Turkish Studies, Vol. 14, No. 1 (2013), pp. 136-157, 147.

38. Barış Kesgin, "Turkey's Erdogan: Leadership Style and Foreign Policy Audiences," Turkish Studies, (February 2019), p. 11.

39. Özgür Özdamar, "Leadership Analysis at a 'Great Distance': Using the Operational Code Construct to Analyse Islamist Leaders," Global Society, Vol. 31, No. 2 (2017), pp. 167-198, 181.

40. Selen Yalaz, "Cumhurbaşkanı Erdoğan'dan S-400 Açıklaması [S-400 Statement from President Erdoğan]," (May 6, 2019), Demirören Haber Ajansı, from https://www.dha.com.tr/politika/ cumhurbaskani-erdogandan-s400-aciklamasi/ haber-1641054.

41. Ankara not only fails to attain the recognition it desires from the US-led order (it is perpetually labeled as authoritarian), it has also been ostracized (the PKK, the main threat of Turkish state, and its branches have gained legitimacy in the West). As Suzuki argues, a state might withdraw from some aspect of the existing hierarchical order because it views its rules as unjust and sees very little stake (and even threat) in maintaining it. See, Suzuki, '"Delinquent Gangs' in International System Hierarchy," p. 227.

42. G. John Ikenberry, "Between the Eagle and the Dragon: America, China, and Middle State Strategies in East Asia," Political Science Quarterly, Vol. 131, No. 1 (2016), pp. 9-43, 35.

43. Stephen M. Walt, "US Grand Strategy after the Cold War: Can Realism Explain It? Should Realism Guide It?" International Relations, Vol. 32, No. 1 (2018), pp. 3-22, 14; Juliet Johnson and Seçkin Köstem, "Frustrated Leadership: Russia's Economic Alternative to the West," Global Policy, Vol. 7, No. 2 (2016), pp. 207-216. 